\title{
ECONOMIZATION, (POST)HUMANIZATION, AND TECHNOLOGIZATION: PERSPECTIVES OF SCHOOL ORGANIZATION MANAGEMENT
}

\author{
Aleksandra Berkowicz* $\odot$ https://orcid.org/0000-0003-4387-7788
}

\begin{abstract}
Background. The article draws thereaders' attention to changes - trends in particular from the environment of further school organizations, and having a significant impact on the way they function.

Research aims. Review and attempt at the theoretical analysis of macro trends: economic, (post) humanities and technology, which governs or will govern education throughout the world. Attention was also paid to challenges posed by individual management perspectives.

Methodology. My research is based on a literature review giving insight into the basic understanding of changes in education and on existing approaches.

Key findings. The article shows that school organizations are subject to various changes initiated by various entities, including political and economic ones and this requires parallel attention to the development of humanities that will allow individuals to become "fully" human, so that entry into the world of nature, economy, technology, society, and culture can be accomplished through awareness and implementation of humanistic ideas.
\end{abstract}

Keywords: education management, school organizations, trends in school management

JEL Codes: I21, I28

\section{INTRODUCTION}

In contemporary reality, there are continuous and various changes of a multifaceted nature: political, social, economic, technological,

\footnotetext{
* Institute of Public Affairs, Jagiellonian University in Kraków. E-mail: aleksandra. zurowska@uj.edu.pl
} 
cultural, and scientific. In the economic and political model created as a result of the processes of globalization, international corporations and governments of highly developed countries are of the greatest importance. Corporations shape the global economic network, influence the development of science and technology, and governments, by supporting domestic enterprises, strengthen their own political and economic position. Competitive advantage is currently achieved through the possession and use of knowledge.

These changes influence the structure of educational institutions and the role they have to play. This is visible in particular in the case of higher education institutions. The term corporation for excellence is used for them. According to this concept, the university is part of a bureaucratic, managerial, and technocratic system. It is becoming a more commercial enterprise than a culture-forming institution. In this way, universities are to contribute to the creation and growth of national income and this is also their social function (Solska, 2011). They cease to exist outside society and they start to exist within the society, also becoming partners (Drucker, 1999) for various entities. An example of this is the concept of the economy based on research and innovation, in which the main role is played by the following triad: higher education institution, business, and government administration. Lower-level schools are also managed following the example of enterprises. In the educational discourse, terms transferred from the economic sector, such as the educational services industry, educational policy of corporatism, and the marketization of education are beginning to dominate. Therefore, a question arises: what changes affect and will affect the education management process?

\section{THE ECOHE ECONOMIC PERSPECTIVE OF CHANGES IN EDUCATION MANAGEMENT}

During the last several decades, the most important global macro-educational trends have included: quality orientation, standardization, evaluation, accountability, and teaching professionalization.

The key change in management in education is quality orientation. Originally, quality concepts had been implemented in enterprises. Over the years, they also penetrated into education. 
In the light of most quality concepts, the constant pursuit of improving products, services, production processes, and human labor allows for making a profit. Similarly, actions have been taken at schools to improve them, in terms of both improving the schools work as an organization and improving educational processes' quality. The authors of the report entitled Education for All: The Quality Imperative indicate two basic elements in the quality of education. The first refers to the cognitive development of students, which should be the goal of any educational system. The second points out the role of education in promoting shared values as well as creative and emotional development. Quality in schools is most often associated with didactic quality, i.e. the quality of teaching processes. This stems out from the easier measurement of learning outcomes than the creative and emotional development of students.

Standardization is another change in global management in education. Standards may be defined in various ways - as a minimum level, averageness, or excellence. The organization may set its own standards, borrow them, or they may be imposed on it. Standards set the direction in which the organization is heading, and their nature can be temporary and priority. They help in planning, ordering activities, specifying and coordinating tasks, and they constitute a reference point and perform a control function (Bednarz, 2013).

However, the adoption of specific standards is usually associated with limiting diversity (Wasilewski, 1998). They are often of an acontextual nature, which means that when they are created, historical and cultural factors of the places where they are to be implemented are not taken into consideration.

The word standardization evokes some ambiguous associations in education. On the one hand, the introduction of standards in schools may be aimed at providing all students with adequate learning conditions that are not inferior to the prescribed standard (Niemierko, 2002), and then the advisability of standardization is fully legitimized. On the other hand, standardization can pose threats such as: automatism of conduct, bureaucracy, inhibiting and limiting the development of talented or creative individuals. The necessity of existence of educational standards is pointed out by A. Nalaskowski (2002), however he does not overestimate their importance. An example given by this Polish educationalist is fluency in the use of English by students. The level of foreign language use by the students is evidenced by: the total number 
of hours per student, the teachers' education and their preparation for the profession, and classroom conditions. These guidelines aimed at confirming compliance with standards in relation to a foreign language deviate from reality and this is not an isolated example.

In education, the greatest emphasis is currently placed on setting individual and institutional standards while the social dimension is often omitted. This may be the effect of the neoliberal policy of Western European countries, for which individualism and development of the market economy are amongthe basic assumptions. The introduction of standards is often initiated by the state, e.g. school curricula standards. For those in power, standards are an opportunity for better management because they help reduce the level of regulatory detail to the essential requirements necessary to achieve the goals set (Bednarz, 2013). In addition, creating standards in the field of education in EU Member States facilitates harmonization. The education policy in many countries is largely managed by standards formulated by experts. They believe that excluding politicians creates some predictability and creates a kind of governing without a government (Lawn \& Grek, 2012).

Important changes that have taken place in education management are partly instruments for introducing standardization, i.e. tests and evaluation. The history of using tests in education goes back to the post-war years. At that time, everyone was granted the right to education (Universal Declaration of Human Rights), as well as the relationships between education and economic growth were noticed. Education has become an important investment for the development of countries.

Currently, one of the most popular international programs examining students' skills is the Program for International Student Assessment (PISA) established in 1997. The coordinator of this research is the international organization named Organization for Economic Co-operation and Development (OECD). The goal of this venture is to evaluate worldwide education systems by testing the knowledge and skills of 15-year-old students in reading, mathematics, and science. Moreover, PISA studies the degree of preparation of young people for adult life and to some extent the effectiveness of education systems. The ambition of those contributing to PISA is to assess achievements in relation to the main goals set by the education system, and not in relation to teaching and learning as knowledge resources. 
The test results had a major impact on shaping public policies in the United States. The Nation at Risk report which was published in 1983 lists a number of education risk indicators based on the test results obtained. They included low test scores of American students, college graduates, higher education institution students compared to the same groups in other countries, functional illiteracy of 23 million American adults, which was reflected in reading, writing, and comprehension tests. Business and military leaders spent millions of dollars on expensive educational recovery programs for recruits on such basic skills as reading, writing, spelling, and counting. This low level of education was considered a threat to the United States' leading position in the global economy. Successive governments sought to improve the quality of education. In recent years, the effect of such activities has been the development of a law called No Child Left Behind. Pursuant to this law, only schools participating in the federal program for controlling the quality of teaching and knowledge mastered by students could receive funding from the government. It has been assumed that the test for teaching quality is meeting statewide standards and the results of school tests conducted among children and adolescents.

Educators and politicians are increasingly interested in measuring student achievement through tests. The growing interest in the results of educational research results in both an explosion of various types of data and a policy oriented on receiving them in the field of education. The results obtained are intended to be useful data in policy making and decision making. Politicians are interested in the information they receive from studies, but little is known about how these data are used by them and whether they are used in an effective way. In addition to those involved in politics, research results can provide feedback for students, teachers, school heads, and parents. It should be highlighted that the assessment of a student or the functioning of a school institution based only on test results is incomplete and carries the risk of "educational fraud" by teachers or school heads to prove that the school meets the necessary requirements.

An important change that has emerged in management in education around the world is school evaluation. It is defined as an "organized and systematic analysis and determination of the degree of implementation by the facility of its requirements resulting from the assigned tasks and expectations of clients" (Uniweska, 2013, p. 42). As written by E. R. House, 
Tens of thousands of public program evaluations are conducted annually in the United States alone. Thousands of people find employment in them, and hundreds of universities and corporations compete with each other for evaluation contracts. Most evaluations are funded by the federal government, the rest - state or local government. The evaluation of public programs has become a legitimate activity, and hundreds of millions of dollars are spent on it each year (House, 1997, p. 15).

In education, information obtained through evaluation can help meet needs, solve educational problems, manage schools, manage funds and promote the school (Szempruch \& Potoczny, 2008). Evaluation performs several significant functions in educational organizations:

- formative - enables organization improvement and development, supports people and programs,

- conclusive - it is used for reporting, certification, accounting and enforcement of responsibility,

- socio-political - affects the motivation and promotion of specific social relations,

- administrative - it is associated with exercising power (Denek \& Hyżak, 2003).

Most often in education where evaluation results from political requirements, the final result oriented (ex post) model, which is also named economic, is used. The measurability and efficiency of teaching and learning play an important role, and tests are the basic means of verifying the results achieved. Evaluation programs created on the basis of this model can also become an instrument for controlling school curricula, a form of social engineering, as well as give rise to dangerous simplifications to education and evaluation (Simons, 1997). The scope of evaluation activities may be wider and deeper than it may result from ex post evaluation. Evaluation can also help in understanding and creating values - equality, respect for dignity, freedom, and justice. Some educationalists prefer a different evaluation model. It is oriented on the learning and teaching process (including results) and is closely related to the main evaluation category, i.e. responsibility. The involvement of the entire school community is enabled by the following types of evaluation:

- dialogical,

- democratic,

- participatory. 
They constitute a social process of self-reflection and they cover many areas both in relation to individuals and the entire organization. For example, in the area of management, they help school community members in making decisions, identifying questions used, identifying and analyzing relevant data on which decisions are based, monitoring the implementation process to make sure it runs properly, recognizing the objective impact and results of decisions made (Idowu). Such evaluations unite the school community's members. They become a mutual diagnosis consisting in collecting data, arriving at their understanding, creating a common understanding of the situation, allow to explore school reality and create a shared vision of a better school (Potulicka, 2006). They stimulate reflection, i.e. an in-depth reflection on the actions taken, and inspire to conduct internal evaluation.

In the United States, public schools have been subjected to pressure from various regulations to improve teacher performance, and the discussion to date has been focusing on the perception of evaluation as a sorting mechanism and a means of selecting those who have demonstrated the lowest efficiency (Taylor \& Tyler, 2012). This has led to many abuses by the school authorities and staff in order to obtain a positive assessment from the supervisory body.

Professionalization is also one of the macro-trends in education. The definition in the sociological dictionary defines professionalization as (Olechnicki \& Załęcki, 1998):

- a process by which a specific set of skills and activities is socially defined and defined as a profession, including the determination of the required scope of knowledge that covers the competences of a given profession;

- a process of activating, strengthening, and developing of the customer-service provider relationship.

The second meaning of the word professionalization is interesting because it draws attention to major market participants and recalls economic descriptive categories. Nevertheless, this approach to professionalism in education is rarely used, and this is mainly in relation to the market-oriented school model. Education is commonly associated with the intellectual sphere of students, teachers and the personality of the educating (Chodakowska \& Mach, 2010) and educated entities.

There are two approaches in the literature describing the issue of professionalism. In the first one, i.e. traditional, professionalism is 
technically understood and identified with experts, i.e. professionals who (Opłocka, 2011):

- focus on the problem, and not on the human being,

- solve problems based on expert knowledge,

- make judgments by referring to stereotypes,

- recognize problems, acknowledging that change is about planning and control by the state,

- distinguish two types of knowledge: "I know that" - acquired in a higher education institution and "I know how" - obtained during practice,

- believe that the source of professionalism is the procedures.

The second approach is the so-called new professionalism. It is devoid of the rules of conduct typical of technical professions. Professionals focus on meeting high standards: cognitive, action, and ethical (Kwiatkowska, 2008). New professionalism is based on three types of professional capital: human, social, and decision-making (Hargreaves \& Fullan, 2012). The concept of human capital refers to knowledge and skills, bringing economic benefits, developed in people through broadly understood education. Human capital in teaching concerns the possession and development of knowledge and skills. At the same time, behind this knowledge and skills lies the knowledge of the subject being taught and how to teach it, understanding the cultural and family conditions of pupils, the ability to empathize with various groups of children and adults connected with the school. In addition, having a passion and moral commitment to serve children and improve in this service (Hargreaves \& Fullan, 2012). Social capital exists in interpersonal relations and, like human capital, contributes to productive activity. Social capital refers to the quantity and quality of interactions and social relationships among people affecting their access to knowledge and information.

Social capital is one of the pillars of transformation of the teaching profession. It can help students from dysfunctional families lacking trust, proper communication, and support in achieving success. In addition, thanks to social capital, a network of co-workers is born that is able to give each other critical feedback. A professional gain and accumulates decision capital through his or her experience, practice, and reflection. This capital enables the teacher to make a reasonable assessment in the absence of rigid rules or compelling evidence. This type of capital is increased through the insights and experience of 
colleagues who make assessments in a wide variety of situations. In teaching and other professions, social capital is an integral part of the decision-making capital, as well as its complement.

The following questions arise in relation to professionalism: Is it imposed on schools from the top? If so, in what form? It should be noted that professionalization requirements are created from the top and they are expressed in various types of regulations. They are aimed at responsible fulfilment of teachers' responsibilities. Thus, for example, organizations in the United States set the diploma requirements that teachers must meet, including professionalism standards that specify the knowledge, skills, and attitudes expected of teachers who start their careers (Hurst \& Reding, 2011). However, modern professionalism is sometimes viewed negatively as a form of professional teacher control. Voices can be heard from educational researchers that the current understanding of teachers' professionalism sets procedural boundaries for them, in line with the "discourse of standards", and professional development comes down to knowledge of current government policies (Davies \& Martin, 2014). Teachers, as potentially the key players, and they can accept or resist external control and defend or reject their autonomy (Evans, 2008). If professionalism is only a tool of the authorities used to force teachers to meet the imposed requirements, accumulating documents proving the acquisition of qualifications, then it does not necessarily lead to a positive transformation of teaching in schools.

In recent years, the concept of accountability has been influencing the education system in many states. This term is used to describe the school's evaluation process, including a number of activities aimed at identifying and enforcing best practices in teacher education, development and teaching (Tatto, 2007). Discharging teachers from the duties fulfilled by direct or indirect stakeholders (Macbeath et al.; 2000) consists in taking responsibility by the teachers for the actions undertaken, including those of a financial nature (Gołębniak, 2003). The effect of the action is explicit or implicit reward or punishment. An example of an explicit reward is a bonus for educators, and an example of an explicit punishment - threats of restructuring or closing low-performance schools. The concealed reward or sanction is less derived from political decision makers taking direct action against the school. Mostly it concerns community pressure on schools to increase their efficiency (Figlio \& Loeb, 2011). There are three main 
types of accountability systems in education that are sometimes used simultaneously (Anderson, 2005):

- compliance with legal regulations - teachers are responsible to the education authorities for applying the rules,

- compliance with professional standards - teachers are responsible to their colleagues for compliance with established standards, e.g. regarding student evaluation,

- results achieved - teachers are responsible to the general public for learning outcomes.

The reasons for increased accountability are present in the environment which schools are part of (Leithwood, 2005). At the same time, the implementation of the accountability system does not always translate into, e.g. improvement of academic, performance. It depends on both the school, including the school community, and the way accountability is understood by political decision-makers.

\section{THE HUMANISTIC PERSPECTIVE OF CHANGES IN EDUCATION MANAGEMENT}

In the beginning, it is worth noting the differences in research goals in the humanities and economics. The humanistic goal is people and increasing their well-being and sense of satisfaction in the organization. In the economic trend, on the other hand, efforts are made to increase the efficiency of organization and management. In the first, the human perspective plays an important role, and in the second it is the market principles. In practice, the two trends usually mix, although they are not equivalent. If organization leaders strive first of all to increase efficiency by objectifying and marginalizing their employees, then such a management method gives rise to "organizational diseases", such as dehumanization for instance. A "healthy organization" is human-oriented. This orientation is expressed, among others in (Beckhard, 1998):

- a sense of purpose and basing on the vision of the future,

- respecting clients and members of the organization,

- wide access to information,

- encouraging and allowing employees to make decisions at the level closest to the client, where all relevant information is accessible. 
In addition, open communication, remuneration systems correlated with work and supporting individual development, functioning in a learning mode, expressing recognition for innovation and creativity, as well as high tolerance for different styles of thinking and ambiguity of all matters play an equally important role.

In the 1970s and 1980s, the processes of dehumanization in schools led to a "disease" and crisis of these organizations. It can be seen that this happened more or less in parallel both in countries such as Poland (at that time an undemocratic state), as well as in the so-called Western democracies. Educational activists and people directly related to the activities of schools (teachers, parents) in Poland and abroad, formulated various proposals regarding school organizations. Schools were contested by the most radical ones, while the moderate proposals postulated their modernization (Nassif, 1979). They were included in the form of the concepts described below, which C. Kupisiewicz (1994) called paradigms.

The first is the paradigm of a society without school (aimed against the schools of that time), where representatives of the theory of descholarization criticized traditional schools, assessing them as alienating and repressive institutions. I. Illich saw in the free, spontaneous, occasional, program-oriented education the realization of proper educational goals. He postulated in particular for the liquidation of schools and the creation of educational networks in their place: "educational services" - centers facilitating access to instruments, apparatus, the so-called "educational subjects" used in formal education (Wurszt, 2002).

The next formulated paradigm referred to alternative schools, which were to have their own developed organizational model, an original identity based on the vision of the school created by one person or a group of people. The concept of the alternative school was to stand out from the background of conventional curricula and goals of elementary schools, and great importance was attached to the maximum use of creative abilities, initiative, independence in thinking and acting of students, teachers and parents. The school atmosphere was to be based on the subjective relationship between teachers and students (Okoń, 1999).

And finally, the third paradigm of the school referred to a constantly improved organization, where traditional schools were to be subjected to constant improvement, continuous processes of modification, improvement in the field of teaching, upbringing and organization. 
It is worth noting that the efforts to increase the humanization of education were also strongly emphasized mainly by representatives of the radical current. In the 1970s, the Brazilian educationalist P. Freire distinguished two concepts: banking model education and education for liberation. The distinguishing features of bank education were, inter alia, the relationship between the teacher and the student and the educational process determined by it (Freire, 1968):

- the teacher teaches and students are taught,

- the teacher knows everything and he or she is the brains and students do not know and have no right to think,

- the teacher speaks and students only listen meekly,

- the teacher disciplines and students are disciplined,

- the teacher makes a choice and imposes his or her choice, and students are to respect this choice,

- the teacher works and the student has the illusion of acting,

- the teacher chooses the curriculum contents, and the student should adapt to this choice,

- the teacher is the subject and the student is the subject of the teaching process.

Education for liberation, on the other hand, consisted of acts of cognition, and not only of providing information, of the dialogical relation necessary to activate cognitive ability and cooperation of educational entities. The pedagogy for liberation:

... consists in making people competent to use their own voice, expressing their own vision of the world, articulating their interests - and in doing so in such a way as to achieve real liberation from the institutionally imposed definitions of situations, to overcome the structural limitations of the learning process (Szkudlarek, 1992, pp. 37-38).

Banking model education was based on the conservative trend and it was characteristic of almost all contemporary schools. The relations between the student and the teacher, described by P. Freire as part of banking model education, were analogous to those between the school head and the teacher, the school head and his or her superior, etc.

This one-way transmission required a conformist attitude and petrified it. Education for liberation was based on the emancipatory trend and was rather an idea of how the school should function. It almost did not occur in educational practice. In today's school organizations one can observe a very slow and selective process of realizing the concept 
of liberation, with the simultaneous dominance of the so-called bank model education.

H. Giroux (2010) is a contemporary representative of critical pedagogy. He shares the opinion that the school is a place of many contradictions and struggles, serving mainly the logic of domination, but also lies in the possibilities of emancipation practices. The critical current in management correlates with the critical current in pedagogy. It constitutes a space for humanization and implementation of the goal, which is involvement in real action and realization of the emancipation idea. The emancipatory power of reason is to be replaced by passive participation in reality and non-reflective reproduction with the awareness of its role in shaping this reality and its development (Zawadzki, 2014). Drawing on the achievements of the critical current in management, school humanization could occur through the implementation of therapy consisting, inter alia, in Sułkowski, 2011:

- creating organizational cultures based on intra-organizational democracy,

- preferring reflectiveness, moral and ethical sensitivity,

- improving the social position of disfavored groups through the use of emancipation methods, i.e. empowerment,

- implementing emancipatory culture at the relationship level,

- creating a reflective and critical culture that will guide the development of organizations, society, and people towards an increase in humanization.

The most important humanistic changes implemented in schools include decentralization and autonomy. Decentralization as a change in education means transferring power from one level to educational institutions (McGinn \& Welsh, 1999). Most often, power is located in the following places: the central government, local government bodies (in Poland it is the province, district, and commune/municipality) and in schools. The educational systems of individual countries are structures adapted to economic, demographic, political and social conditions, which have been shaped over the years as a result of slow reconstruction or turbulent changes (Nowak-Kania, 2012). In European countries, the combination of centralized and decentralized education systems is most common.

The United States has the most decentralized education system in the world. The centralized system is more efficient in administrative terms than a decentralized one since decisions are made only at the 
highest level. In this system, it is possible to establish uniform procedures for school buildings, recruitment and training of employees, and staff remuneration. In addition, educational standards can be developed and implemented through central management. The decentralized system is characterized by making decisions at lower levels and, as a consequence, a differentiated approach to areas such as staffing or school infrastructure. The advantage of this system is the ability to respond faster to local needs and interests (Cummings, 2003) and changing educational trends.

Decentralization contributes to autonomy. It should be understood in educational systems as a form of management, in which schools constitute the decision-making body in relation to its activities (Arcia et al., 2011). The autonomous school concepts implemented the so-called charter schools, i.e. schools with a special statute. They started to be established in the United States in the 1980s. The primary principle of these schools is independence and freedom of action which increases the innovativeness of school staff, thus leading to increased student achievement. In addition, the founding document is a guarantee of school autonomy, limiting top-down management (Kubiczek, 2002). The distinguishing feature of charter schools is the cooperation covering all educational entities, especially parents, enabling them to get involved in school matters. Apart from that, teachers' freedom in undertaking various initiatives is important. The entire structure organized in such a way is primarily intended for the development of students. Currently, this type of school is partly financed by government authorities, and in return they are obliged to meet the school community's planned educational goals included in the founder's charter.

All members of the school community can play an important role in an autonomous school. Including autonomy in schools means moving away from focusing on ideology, society, or the state, and placing the human being in the center as the main participant in the educational process, whom education is to serve, allows to develop and shape him or her (Wiśniewska-Paź, 2009). Autonomous actions seem to be particularly important in a society where knowledge constitutes a value. The labor force is beginning to be created by educated employees capable of self-management and working in self-managing teams (Mazurkiewicz, 2010-2011). Autonomy is one of the conditions for realizing this ability. Without decentralization and autonomy, teachers become only executors of the educational policy. 
Both decentralization and autonomy are described in more detail in chapter two of the paper.

The research conducted in 2010 by G. Mazurkiewicz in the Lesser Poland Province (Mazurkiewicz, 2012) reports on the school models that prevail for instance in Polish education. According to them, the main task of institutions and the education system, in the opinion of school heads, is to prepare students for life in the society, either by internalizing the existing rules and norms by them, or by providing them with knowledge or enabling them to acquire skills necessary to find a job. In addition, education is seen as a production process, and not a place of democratic practices. This proves a somewhat narrow and limited mental model of education presented by school managers and, in effect, the creation of traditional and marketized schools.

The implementation of the humanistic approach in schools is facilitated by their adoption of a modern management concept called the learning organization. P. Senge, one of the creators of the idea of the learning organization, stated that:

it is no longer possible to set goals at the top of the organization and to instruct its other members to follow the path set by the "great strategist". Organizations that will really win in the future will be those that discover how to use human commitment and learning opportunities at all levels (Senge, 1998, p. 17).

Whether schools become learning organizations depends on those who decide about the shape of education, as well as all school community members, in particular school heads and teachers. The key task is to build learning organizations that enable "development in line with the needs and aspirations, and in addition the acceptance of the fact that it is easiest to achieve this by supporting the development of employees and strengthening their sense of responsibility and autonomy" (Mazurkiewicz, 2011, p. 249).

In relation to ontological and epistemological transformations as well as technological and scientific transformations of the $20^{\text {th }}$ and $21^{\text {st }}$ centuries, the concept of "posthuman" expressed in posthumanism and transhumanism appeared. The idea of posthumanism means views associated with the change in perception of human position in the world not only among other living beings, but also machines, artificial intelligence and artificial life (Zawojski, 2017). Transhumanism problematizes modern understanding of man not through his past and 
present heritage but the possibilities inscribed in his biological and technological (auto)evolutionary potential (e.g. regenerative medicine, nanotechnology, radical life extension) (Ferrando, 2016).

Technology is a common area for posthumanism and transhumanism, although it is not the goal for the first trend. The question remains whether post- and transhumanisms help cope with innovation by redefining humanity or do they mainly multiply controversies and lead to the danger associated with moral relativism or the superiority of technology and human progress? Certainly, rapid economic and technological changes require a humanistic (re)vision of humanity but is the hierarchy of universal values not enough? The world of axiology carries the potential of insufficient awareness and materialization by man.

\section{THE TECHNOLOGICAL PERSPECTIVE OF CHANGES IN EDUCATION MANAGEMENT}

In addition to the economic and humanistic dimension of management, there is also a technological dimension. Technology in the common understanding means manufactured items. Their goal is either to increase human abilities or to enable people to perform tasks that they would not be able to do on their own. Engineers call these objects equipment, and anthropologists talk about artifacts (Grubler, 2003). In addition, technology is defined as knowledge, activities, processes, and values. The most important distinguishing features of technology are: uncertainty, dynamics, systemicity, and cumulativeness. Uncertainty occurs at every stage of technological evolution - from project selection to environmental impact or potential side effects. There are no effective ways to avoid uncertainty beyond the strategy of experimenting with technological diversity. Technology is dynamic - it is permanently changing. These changes bring new variations, continuous improvement, and modification. The systemicity of technology does not mean an isolated, discrete event that affects only one artifact. New technology requires invention, projection, but also production, which entails the involvement of further technologies, i.e. infrastructure. Production systems should be considered in terms of their interaction with technological, institutional, and social systems. Cumulativeness 
refers to previous knowledge and experience since most artifacts are rarely built "from scratch" (Grubler, 2003).

The oldest approach to education technology is craft-oriented approach. In this approach, the goal is to learn craft skills, the final product is evaluated. The main role here is action, creating artifacts. In Eastern European countries, the approach to technology as the process of mainly industrial production used to dominate. Design-based activity is another approach popular in England. The primary goal of the program is to stimulate creativity and design skills of students. It is not the work effect, but the process that plays an important role in assessing students' work. Orientation on "high tech" applies to advanced artifacts such as computers, robots, and other automated systems. In France or Israel for instance, this approach is often promoted. However, the implementation of this type of internship into schools requires large financial outlay and an appropriate infrastructure. The next approach is orientation towards the use of science.

Technology is the context for teaching the sciences. The next approach is focused on key competences. It is about knowledge and skills such as cooperation, organization, responsibility, and taking initiatives. A focus on engineering concepts is close to the competence-oriented approach. Here, technology is also seen from the angle of knowledge. Students in German schools, for example, made theoretical analyses of systems in which they had to identify the flow of energy and information. Orientation to social aspects is primarily technology as a value. In Sweden, students learned about the social effects of technology and dealt with ethical questions about technology and people. Many Science, Technology, Society (STS) curricula have been developed in line with this approach. Currently, considering globalization processes, exchange of ideas and information, most countries do not focus only on one approach but on their combinations to create a more sustainable technology curriculum (Williams, 2012).

In the American Horizon Report 2016 for K-12 - the stage of education covering compulsory kindergartens, elementary, and secondary schools, 12 grades in total - an attempt was made to answer the question what trends and technologies would drive education and in the face of which challenges effective solutions would need to be planned.

Trends have been identified in three time perspectives. It is worth noting the short-term perspective, because it refers to the students' acquisition of new technical skills - learning programming, which would 
be implemented in kindergartens and primary schools in parallel with learning to read and write, and creative - learning various subjects, but not only by passing theoretical knowledge but by undertaking creative activities using digital tools or mobile technologies. The consequence of the technological changes taking place is the medium-term perspective: Collaborative Learning, Deeper Learning Approaches and the long-term perspective: Redesigning Learning Spaces and Rethinking how schools work.

Technological progress in schools that will take place within one year or even less will be manifested by creating makerspaces - informal workshop environments - creative spaces offering both tools and the possibilities of learning and creating as well as Online Learning, i.e. learning via the network. It has a wide range of possibilities in relation to individuals: the ability to take courses at any time, access to various materials, and in the social dimension - equalizing educational opportunities. Robotics and virtual reality are technologies adapted to education in 2 or 3 years. Robotics is the design and use of robots. Thanks to them it is possible to simulate, observe, and understand complex projects. It promotes the development of critical thinking, and it can provide support and assistance to people affected by communication and social difficulties. Virtual reality is the computer-generated environment that simulates the physical presence of people and objects, providing realistic sensory experiences. Artificial intelligence (AI) and wearable technology will be implemented in schools within $4-5$ years. AI has the potential to increase online learning opportunities, adaptive learning software and simulations in ways that more intuitively respond to and engage with students.

Wearable technology is intelligent devices worn by students. Wearable technologies help users adjust their behaviors to achieve goals. Schools are also introducing wearables into physical education (PE) classes to personalize the curriculum through real-time feedback and grades based on individual skill mastery.

Technological changes bring a new model of management as well as teaching and learning, which, however, is still poorly recognized in Poland, including professionalization and individualization of education. School heads and school teachers will have to answer the questions what new things coming from technology can be adapted at schools, how to teach in a rapidly changing student environment and what activities will bring benefits (Sysło, 2005). 


\section{CONCLUSIONS}

In the face of trends that education has been subject to for several decades, a question arises whether education serves only as a means for winning in the business economic race (Danilewska, 2008). Do the introduced changes aim at comprehensive human development based on humanistic values?

One of the threats to education is the distortion of the balance between its economic and humanistic perceptions, mainly by policy makers as lawmakers and key stakeholders in developing public policies. The advantage of the economic trend can be manifested in predetermined goals, mandatory and inflexible curricula, bureaucracy, overloading with political initiatives or pressure to meet certain goals (MacBeath, 2000). As a result, you can often see teachers' dissatisfaction with the loss of control over the teaching process resulting from introducing seemingly beneficial solutions for schools and education. Another challenge is technology, which becomes an integral part of life, but brings with it both opportunities and difficulties. Including technology in education management is a costly undertaking not only because of its implementation here and now, but also because of its rapid aging. The exclusivity of technology can generate new social and international divisions. In addition, the use of technological developments requires defining a moral vision, a social contract thanks to which society will know what is valuable and important (Cloete, 2017). The main threat in the modern world in the context of ongoing changes, which are influenced by school organizations, is the indifferentism regarding moral and social sensitivity and broadly understood humanism. The challenge facing schools is to support and help each individual in becoming fully human because this vision continues to be utopian.

Humanization aims at human development and improvement. The school, as an organization consciously creating and propagating values and educating future citizens, cares for the humanity of the individuals. Education, understood as the acquisition of various competences in the name of economic development, socializes individuals who are willing to compete and fight (Szumigraj, 2005). The market and technological vision can cause both institutional destruction of the school and personality destruction of the people educated there. The school's institutional destruction consists in 
excessive centralization of management, increasing and ideological control of education. Personality - in the inability to take responsibility and self-direction, but being subject to discipline and various forms of power and loss of liberty (Potulicka, 2010). Not taking humanistic aspects in educational changes into account or creating the appearances of humanization undermines the chances of higher development for which man was called.

\section{REFERENCES}

Arcia, G., Macdonald, K., Patrinos, H. A. \& Porta, A. (2011). School autonomy and Countability. SABER.

Bakkowski, A., Anderson, J. A. (2005). Accountability in Education. Paris: UNESCO. Beckhard, R. (1998). Zdrowa organizacja. In: F. Hasselbein, M. Goldsmith \& R. Beckhard (eds.), Organizacja przyszłości (pp. 359-360). Warszawa: Business Press.

Bednarz, L. (2013). Standaryzacja pracy i zasobów w strumieniu wartości. In: R. Knosala (ed.), Innowacje w zarzadzaniu i inżynierii produkcji (pp. 445-456). Warszawa: Oficyna Wydawnicza Polskiego Towarzystwa Zarządzania Produkcja.

Chodakowska, M. \& Mach, A. (2010). Profesjonalizm w wychowaniu specjalnym. In: U. Gruca-Miasik, A. Tokarova \& E. Lukac (eds.), Profesjonalizm w opiece, wychowaniu i pracy socjalnej (p. 124). Rzeszów: Wydawnictwo Uniwersytetu Rzeszowskiego.

Cloete, A. L. (2017). Technology and eductaion: Challenges and opportunities. HTS Teologiese Studies, 73(4), 2-6.

Cummings, E. W. (2003). The Institutions of Education. United Kingdom: Symposium Books.

Danilewska, J. (2008). Edukacyjny doping ery globalizacji - czy potrafimy go zrównoważyć. In: J. Danilewska (ed.), Wspólnota pedagogicznego niepokoju. Kraków: Wydawnictwo Uniwersytetu Jagiellońskiego.

Davies, T. \& Martin, D. (2014). Przywództwo i zarządzanie w edukacji wobec globalnych przemian. In: G. Mazurkiewicz (ed.), Edukacja jako odpowiedź. Odpowiedzialni nauczyciele w zmieniajacym się świecie. Kraków: Wydawnictwo Uniwersytetu Jagiellońskiego.

Denek, K. \& Hyżak, D. (2003). Ewaluacja jakości pracy nauczyciela w kontekście jego awansu zawodowego. In: R. Cierzniewska (ed.), Ewaluacja jakości pracy nauczyciela. Bydgoszcz: Wydawnictwo Akademii Bydgoskiej im. Kazimierza Wielkiego. 
Drucker, P. (1999). Społeczeństwo pokapitalistyczne. Warszawa: Wydawnictwo Naukowe PWN.

EFA Global Monitoring Report 2005 (2005). Education for All: The Quality Imperative, http://unesdoc.unesco.org/images/0013/001373/137334e.pdf (accessed: $9^{\text {th }}$ December 2014).

Evans, L. (2008). Professionalism, professionality and the development of education professionals, British Journal of Educational Studies, 56 (1), 20-38.

Ferrando, F. (2016). Posthumanizm, transhumanizm, antyhumanizm, metahumanizm oraz nowy materializm. Różnice i relacje. Rocznik Lubuski, 42(2).

Figlio, D. \& Loeb, S. (2011). School accountability. In: E. Hanushek, S. Machin, L. Woessmann \& B. V. Elsevier (eds.), Economics of Education, 3.

Freire, P. (1968). Pedagogy of the Oppressed. New York: Seabury Press.

Giroux, H. A. (2010). W kierunku nowej sfery publicznej. In: H. A. Giroux \& L. Witkowski (eds.), Edukacja i sfera publiczna. Kraków: Impuls.

Gołębniak, B. D. (2003). Ewaluacja - „nowy” lejtmotyw edukacji nauczycieli. In: R. Cierzniewska (ed.), Ewaluacja jakości pracy nauczyciela. Bydgoszcz: Wydawnictwo Akademii Bydgoskiej im. Kazimierza Wielkiego.

Grubler, A. (2003). Technology and Global Change. Cambridge: Cambridge University Press.

Hargreaves, A. \& Fullan, M. (2012). Professional Capital. Transforming Teaching in Every School. New York: Routledge.

House, E. R. (1997). Ewaluator w społeczeństwie. In: L. Korporowicz (ed.), Ewaluacja w edukacji. Warszawa: Oficyna Naukowa.

Hurst, B. \& Reding, G. (2011). Profesjonalizm w uczeniu. Warszawa: Oficyna Wolters Kluwer Business.

Idowu, A. A. The role of educational evaluation in educational development of Nigeria. https://www.academia.edu/22 644 100/THE_ROLE_OF_EDUCATIONAL_EVALUATION_IN_EDUCATIONAL_DEVELOPMENT_OF_NIGERIA (accessed: $28^{\text {th }}$ December 2014).

IIEP, History. http://www.iiep.unesco.org/en/institute/history (accessed: $13^{\text {th }}$ December 2014).

Jelonek, M. \& Skrzyńska, J. (2010). Jakość kształcenia w szkolnictwie wyższym. In: W. Przybylski, S. Rudnicki \& A. Szwed (eds.), Ewaluacja jakości dydaktyki w szkolnictwie wyższym. Kraków: Wyższa Szkoła Europejska im. ks. J. Tischnera.

Kubiczek, B. (2002). Autonomia szkoty. Opole: Wydawnictwo Nowik.

Kupisiewicz, C. (1994). Paradygmaty i wizje reform oświatowych. Warszawa: Wydawnictwo Akademickie Żak. 
Kwiatkowska, H. (2008). Pedeutologia. Warszawa: Wydawnictwa Akademickie i Profesjonalne.

Lawn, M. \& Grek, S. (2012). Europeanizing Education Governing a New Policy Space. Oxford: Symposium Books.

Leithwood, K. (2005). Educational Accountability: Issues and Alternatives. Toronto: Saskatchewan School Boards Association.

MacBeath, J. (2012). Future of Teaching Profession. http://download.ei-ie.org/ Docs/WebDepot/EI\%20Study\%20on\%20the\%20Future\%20of\%20Teaching\%20 Profession.pdf (accessed: 12 $2^{\text {th }}$ April 2015).

Macbeath, J., Schratz, M., Meuret, D. \& Jakobsen, L. (2000). Czy nasza szkoła jest dobra? Warszawa: WSiP.

Mazurkiewicz, G. (2010-2011). Po co szkołom ewaluacja? In: G. Mazurkiewicz (ed.), Autonomia. Kraków: Wydawnictwo Uniwersytetu Jagiellońskiego.

Mazurkiewicz, G. (2011). Przywództwo edukacyjne. Odpowiedzialne zarzqdzanie edukacjq wobec wyzwań wspótczesności. Kraków: Wydawnictwo Uniwersytetu Jagiellońskiego.

Mazurkiewicz, G. (2012). Edukacja i przywództwo. Modele mentalne jako bariery rozwoju. Kraków: Wydawnictwo Uniwersytetu Jagiellońskiego.

McGinn, N. \& Welsh, T. (1999). Decentralization of Education: Why, When, What and How? Paris: UNESCO.

Mikuła, B. (2000). Człowiek a organizacja. Humanizm w koncepcjach $i$ metodach organizacji i zarzadzania XX wieku. Kraków: Oficyna Wydawnicza Drukarnia Antykwa s.c.

Müller, A. (2004). Globalizacja - mit czy rzeczywistość. In: E. Czarny (ed.), Globalizacja od A do Z. Warszawa: Narodowy Bank Polski.

Nalaskowski, A. (2002). Widnokregi edukacji. Kraków: Impuls.

Nassif, R. (1979). Teoria deskolaryzacji: między paradoksem a utopia. In: C. Kupisiewicz (ed.), Nowoczesność w kształceniu i wychowaniu. Wybór artykułów z kwartalnika „Perspectives” wydawanego przez UNESCO. Warszawa: WSiP.

Nation at Risk. https://www2.ed.gov/pubs/NatAtRisk/risk.html (accessed: $17^{\text {th }}$ December 2014).

Niemierko, B. (2002). Ocenianie szkolne bez tajemnic. Warszawa: WSiP.

Nowak-Kania, M. (2012). Europejskie systemy edukacyjne. In: E. Trafiałek (ed.), Zarzadzanie oświata. Elementy organizacji, rozwoju i modernizacji systemu. Kielce: Uniwersytet Jana Kochanowskiego w Kielcach.

OECD (1999). Measuring Student Knowledge and Skills. A New Framework for Assessment. Paris: OECD. http://www.oecd.org/edu/school/programmeforinternationalstudentassessmentpisa/33693997.pdf (accessed: $14^{\text {th }}$ December 2014). 
OECD (2012). Educational Today 2013. The OECD Perspective. https://www.oecd-ilibrary.org/docserver/edu_today-2013-en.pdf?expires=1582669647\&id=id\& accname=guest\&checksum=EFE3A84E237CA3627C250D3E2CB92B7A (accessed: $14^{\text {th }}$ December 2014).

OECD (2018). About PISA. http://www.oecd.org/pisa/aboutpisa/ (accessed: $14^{\text {th }}$ December 2014).

Okoń, W. (1999). Dziesięć szkót alternatywnych. Warszawa: WSiP.

Olechnicki, K. \& Załęcki, P. (1998). Stownik socjologiczny. Warszawa: PWN.

Opłocka, U. (2011). Na drodze do profesjonalizmu. Wrocław: Biblioteczka Refleksyjnego Praktyka.

Patton, M. Q. (2013). Przyszłe trendy w ewaluacji. In: A. Haber \& Z. Popis (eds.), (R)ewaluacja. Poszukiwanie nowych metod oceny efektów. Warszawa: Polska Agencja Rozwoju Przedsiębiorczości.

Potulicka, E. (2006). Ewaluacja dla rozwoju szkoły. In: B. Muchacka (ed.), Szkoła $w$ nauce i praktyce edukacyjnej. Kraków: Impuls.

Potulicka, E. (2010). Teoretyczne podstawy neoliberalizmu a jego praktyka. In: E. Potulicka \& J. Rutkowiak (eds.), Neoliberalne uwiktania edukacji. Kraków: Impuls.

Senge, P. (1998). Piata dyscyplina. Teoria i praktyka organizacji uczacych się. Warszawa: Dom Wydawniczy ABC.

Simons, H. (1997). Proces ewaluacji w szkołach. In: H. Mizerek (ed.), Ewaluacja w szkole. Wybór tekstów. Olsztyn: Wydawnictwo MG.

Solska, E. (2011). Duch liberalizmu a projekt europejskiej przestrzeni edukacyjnej. Lublin: Wydawnictwo Uniwersytetu Marii Curie-Skłodowskiej.

Sułkowski, Ł. (2011). Krytyczna wizja kultury organizacyjnej. Problemy Zarzqdzania, $9,4(34)$.

Sysło, M. M. Rozwój technologii informacyjnej a edukacja-stan, kierunki, wyzwania. http://www.ptde.org/pluginfile.php/11/mod_page/content/19/2.pdf (accessed: $11^{\text {th }}$ November 2019).

Szempruch, J. \& Potoczny, J. (2008). Ewaluacja edukacyjna czynnikiem stymulujacym rozwój szkoły. In: J. Grzesiak (ed.), Ewaluacja i innowacje w edukacji. Ewaluacja w dialogu-dialog w ewaluacji. Kalisz-Konin: Państwowa Wyższa Szkoła Zawodowa w Koninie.

Szkudlarek, T. (1992). Pedagogika wyzwolenia. In: T. Szkudlarek \& B. Śliwerski (eds.), Wyzwania pedagogiki krytycznej i antypedagogiki. Kraków: Impuls.

Szumigraj, M. (2005). Niewolnik korporacji i outsider, czyli kim być w świecie (bez) zatrudnienia, albo o produktach edukacji. In: A. Kargulowa, S. M. Kwiatkowski \& T. Szkudlarek (eds.), Rynek $i$ kultura neoliberalna a edukacja. Kraków: Impuls. 
Tatto, M. T. (2007). Reforming Teaching Globally. United Kingdom: Symposium Books. Taylor, E. S. \& Tyler, J. H. (2012). Can Teacher Evaluation Improve Teaching? http:// educationnext.org/can-teacher-evaluation-improve-teaching/ (accessed: $28^{\text {th }}$ December 2014).

Uniweska, A. (2013). O jakości pracy szkoty. Toruń: Wydawnictwo Naukowe Uniwersytetu Mikołaja Kopernika.

Wasilewski, L. (1998). Podstawy zarzadzania jakością. Warszawa: Wydawnictwo Wyższej Szkoły Przedsiębiorczości i Zarządzania im. L. Koźmińskiego.

Williams J. (2012). Technology Education for Teachers. Rotterdam-Boston-Taipei: Sense Publisher.

Wiśniewska-Paź, B. (2009). Autonomia edukacji a ład społeczny. Struktura szkolnictwa w Szwajcarii wobec zdecentralizowanej koncepcji społeczeństwa i państwa. Warszawa: Wydawnictwo Naukowe Semper.

Wolanin, T. R. (2011). Aby żadne dziecko nie pozostawało $w$ tyle. Edukacja $w$ USA. Warszawa: Oficyna Wolters Kluwer Business.

Wurszt, H. (2002). Ivan Illich i jego system. http://edukacjaidialog.pl/archiwum/2002, 100/maj,179/ivan_illich_i_jego_system,1309.html (accessed: $5^{\text {th }}$ April 2013)

Zawadzki, M. (2014). Nurt krytyczny w zarzadzaniu. Kultura, edukacja, teoria. Warszawa: Sedno.

Zawojski, P. (2017). Posthumanizm, czyli humanizm naszych czasów. Kultura $i$ Historia, 32 .

\title{
EKONOMIZACJA, POSTHUMANIZACJA I TECHNOLOGIZACJA. PERSPEKTYWY ZARZĄDZANIA ORGANIZACJA SZKOLNA
}

\begin{abstract}
Abstrakt
Tło. W artykule zwrócono uwagę na współczesne zmiany - trendy, które odnoszą się także do organizacji szkolnych i mają znaczny wpływ na sposób ich funkcjonowania.

Cele badawcze. Przegląd oraz próba teoretycznej analizy makrotrendów: ekonomizacji, (post)humanistyki i technologizacji, które wpływają i będą wpływać na edukację na całym świecie. W artykule przedstawiono także wyzwania wynikające z poszczególnych perspektyw zarządzania.
\end{abstract}

Metodologia. Badania opierają się na przeglądzie literatury, dajacym wgląd w występujacce współcześnie zmiany i zrozumienie istniejących podejść w kontekście edukacji. 
Kluczowe wnioski. Organizacje szkolne podlegają zmianom inicjowanym przez różne podmioty, w tym polityczne, gospodarcze, a to wymaga równoległego rozwoju i wdrażania podejścia humanistycznego, które pozwoli jednostkom stać się „w pełni” ludźmi. Po to, aby wejść w świat przyrody, ekonomii, technologii, społeczeństwa i kultury ze świadomością oraz realizacją humanistycznych idei.

Słowa kluczowe: zarządzanie edukacja, organizacje szkolne, trendy w zarządzaniu edukacją 